\title{
Neonatal mortality associated with sodium monofluoracetate in kids fed with colostrum from goats ingesting Amorimia septentrionalis ${ }^{1}$
}

\author{
José R.G. Lopes ${ }^{2 *}$ (D), José A.S. Araújo ${ }^{3}$, Danielle A.N. Pessoa², Stephen Lee ${ }^{4}$, \\ Daniel Cook ${ }^{4}$, Franklin Riet-Correa ${ }^{2,5}$ and Rosane M.T. Medeiros ${ }^{2}$
}

\begin{abstract}
Lopes J.R.G., Araújo J.A.S., Pessoa D.A.N., Lee S., Cook. D., Riet-Correa F. \& Medeiros R.M.T. 2019. Neonatal mortality associated with sodium monofluoride in kids fed with colostrum from goats ingesting Amorimia septentrionalis. Pesquisa Veterinária Brasileira 39(3):163-167. Hospital Veterinário, Centro de Saúde e Tecnologia Rural, Universidade Federal de Campina Grande, Avenida Universitária s/n, Bairro Santa Cecília, Patos, PB 58780-110, Brazil. E-mail: macyo_mv@hotmail.com

Sudden deaths after colostrum ingestion in kids and lambs born to mothers grazing in areas with Amorimia septentrionalis have been reported in the Brazilian northeastern semi-arid region, in Paraíba state. This study aimed to determine whether the sodium monofluoracetate (MF) contained in A. septentrionalis is eliminated in milk, causing the death of kids. After confirming gestation on the 25th day after mating, 26 goats were randomly distributed into three groups. In Group 1, eight goats received fresh leaves of A. septentrionalis in daily doses of $1 \mathrm{~g} / \mathrm{kg}$ body weight, administered at three different periods during gestation: from days 91 to 100,116 to 125, and from day 140 until delivery day. In Group 2, consisting of 10 females, eight goats received $1 \mathrm{~g} / \mathrm{kg}$ body weight of A. septentrionalis dried and milled leaves, fed daily from the 140th day of gestation until delivery. The other two goats of this group did not ingest the plant during gestation and after delivery the colostrum supplied to their kids was replaced by colostrum of goats from that same group that had ingested the plant. Eight goats from Group 3 (control) did not ingest $A$. septentrionalis. Seven goats from Group 1 showed signs of poisoning from 2 nd to 8th days of plant administration, in all periods, and recovered within 7 to 12 days. Another goat presented severe clinical signs and was submitted to euthanasia in extremis. Two goats aborted. Four kids, from two goats, received colostrum and, after 15 minutes, presented depression, breathing wheezing, lateral recumbence, bleating, and death. Two goats gave birth at night; the two kids were found dead and, at necropsy, it was verified that they were born alive. The last goat in this group gave birth to two kids which showed no signs of poisoning after colostrum ingestion. In Group 2, the eight goats that ingested dry leaves of the plant presented tachycardia and engorgement of the jugular veins; six aborted, and the kids of the other two goats died immediately after delivery without ingesting colostrum. The three kids of the two goats that did not ingest the plant during gestation did not show signs of poisoning after ingesting colostrum from the goats that had ingested the plant. In Group 3, all females kidded normally and the kids showed no signs of poisoning. Ten leaf
\end{abstract}

\footnotetext{
${ }^{1}$ Received on September 3, 2018.

Accepted for publication on October 9, 2018.

${ }^{2}$ Hospital Veterinário, Centro de Saúde e Tecnologia Rural (CSTR), Universidade Federal de Campina Grande (UFCG), Avenida Universitária s/n, Bairro Santa Cecília, Patos, PB 58780-110, Brazil. *Corresponding author: macyo_mv@hotmail.com
}

\footnotetext{
${ }^{3}$ Escola Superior Batista do Amazonas (ESBAM), Rua Leonor Teles 153, Adrianópolis, Manaus, AM 69057-510, Brazil.

${ }^{4}$ Poisonous Plant Research Laboratory, Agricultural Research Service, United States Department of Agriculture, University Hill Way, Logan, UT 84322, USA.

${ }^{5}$ Instituto Nacional de Investigación Agropecuaria (INIA), La Estanzuela, Ruta $50 \mathrm{Km}$ 11, Colonia Uruguay.
} 
samples of A. septentrionalis contained $0.00074 \% \pm 0.00018$ MF. These results demonstrate that the MF of A. septentrionalis is eliminated in colostrum and may cause the death of kids. As in previous reports, the plant also caused abortion.

INDEX TERMS: Neonatal mortality, sodium monofluoracetate, colostrum, goats, kids, Amorimia septentrionalis, toxins in milk, abortion, plant poisoning, toxicoses.

RESUMO.- [Mortalidade neonatal associada ao monofluoroacetato de sódio em cabritos alimentados com colostro de cabras ingerindo Amorimia septentrionalis.] Mortes súbitas, após a ingestão do colostro, em cabritos e cordeiros nascidos de mães que pastejam em áreas com Amorimia septentrionalis são relatadas no semiárido da Paraíba. 0 objetivo deste trabalho foi determinar se o monofluoracetato de sódio (MF) contido em Amorimia septentrionalis é eliminado pelo leite, causando a morte dos cabritos. Após a confirmação da gestação no 25ำ dia após a cobertura, 26 cabras foram aleatoriamente distribuídas em três grupos. No Grupo 1, oito cabras receberam folhas frescas de $A$. septentrionalis em doses diárias de $1 \mathrm{~g} / \mathrm{kg}$ de peso vivo, administradas em três períodos diferentes durante a gestação: entre os dias 91 a 100, 116 a 125 e do $140^{\circ}$ dia até o parto. No Grupo 2, composto por 10 fêmeas, oito cabras receberam $1 \mathrm{~g} / \mathrm{kg}$ de peso vivo de folhas secas e trituradas de $A$. septentrionalis, fornecida diariamente do $140^{\circ}$ dia de gestação até o parto. As outras duas cabras desse grupo não ingeriram a planta durante a gestação e, ao parirem, o colostro fornecido aos seus cabritos foi substituído pelo colostro de cabras, desse mesmo grupo, que ingeriram a planta. Oito cabras do Grupo 3 (controle) não ingeriram A. septentrionalis. Sete cabras do Grupo 1 apresentaram sinais de intoxicação entre o $2^{\circ}$ e $8^{\circ}$ dia de administração da planta, em todos os períodos, e se recuperavam em 7 a 12 dias. Outra apresentou sinais clínicos graves e foi eutanasiada in extremis. Duas cabras abortaram. Quatro cabritos, oriundos de duas cabras, receberam colostro e, após 15 minutos, apresentaram depressão, respiração ofegante, decúbito lateral, berros e morte. Dois cabritos, nascidos de duas cabras que pariram durante a noite, foram encontrados mortos e os achados de necropsia permitem afirmar que nasceram vivos. A outra cabra desse grupo pariu dois cabritos que, mesmo mamando o colostro, não apresentaram sinais de intoxicação. No Grupo 2 , as oito cabras que ingeriram a planta seca apresentaram taquicardia e ingurgitamento das veias jugulares; seis abortaram e os cabritos das outras duas morreram imediatamente após o parto, sem ingerir colostro. Os três filhotes das duas cabras que não ingeriram a planta durante a gestação não apresentaram sinais de intoxicação após ter ingerido colostro das cabras que tinham ingerido a planta. No Grupo 3, todas as fêmeas pariram normalmente e os filhotes não apresentaram sinais de intoxicação. Dez amostras de folhas de A. septentrionalis continham $0,00074 \% \pm 0,00018$ de MF. Estes resultados demonstram que o MF de A. septentrionalis, além de causar abortos, é eliminado pelo colostro podendo causar a morte dos cabritos.

TERMOS DE INDEXAÇÃO: Mortalidade neonatal, monofluoroacetato de sódio, cabritos, colostro, Amorimia septentrionalis, toxinas no leite, aborto, caprinos, intoxicação por planta, toxicoses.

\section{INTRODUCTION}

Sodium monofluoracetate (MF) has been identified as a toxic agent in several plants, causing sudden death associated with exercise (Tokarnia et al. 2012). In Brazil, 12 toxic plant species belonging to families Rubiaceae, Bignoniaceae, and Malpighiaceae are known to cause this syndrome (Carvalho et al. 2009). Dueto their acute toxicity, good palatability, and wide geographical distribution, these plants are among the most important toxic plants for ruminants in the Country (Tokarnia et al. 2012).

In the Brazilian northeastern semi-arid region, mainly in the states of Ceará, Paraíba, and Pernambuco (Albuquerque et al. 2014), poisoning with Amorimia septentrionalis is the most known, widespread and important cause of sudden death in ruminants (Duarte et al. 2013). There are reports of poisoning outbreaks by this plant in sheep and goats in the state of Paraíba, with poisoning occurring mainly at the beginning of the rainy season, when these plants sprout before other forage plants, or after that period, when some forage plants dry (Vasconcelos et al. 2008).

The following clinical signs have been observed in experimentally poisoned goats: dyspnea, tachycardia, and sternal decubitus evolving to lateral decubitus with peddling movements followed by death. Some less affected animals recover. No significant lesion has been described in the necropsy of poisoned animals (Paraguassu 1983), although, histologically, hydropic-vacuolar degeneration of the renal tubular epithelial cells have been observed in some poisoned ruminants (Tokarnia et al. 2012); and in smaller doses ingested for prolonged periods, plants containing MF may cause cardiac fibrosis (Soares et al. 2011).

In addition to causing sudden death syndrome, ingestion of $A$. septentrionalis results in embryonic mortality and abortions in goats (Silva et al. 2017). Goat and sheep raisers in the semi-arid region of Paraíba state have reported that kids and lambs, born to animals that grazed on areas with plants of the Amorimia genus during gestation, have died suddenly after colostrum ingestion, suggesting that MF can be excreted in milk, causing the death of kids. This route of elimination of the active principle constitutes a risk to public health, because of the possibility of human consumption of milk from animals that ingest $A$. septentrionalis.

Aiming to experimentally investigate the elimination of MF in milk, the objective of this study was to verify the occurrence of poisoning of kids fed with colostrum from goats that ingested Amorimia septentrionalis.

\section{MATERIALS AND METHODS}

The experiment was conducted at the Hospital Veterinário of Universidade Federal de Campina Grande (UFCG). Twenty-six goats and two male goats, crossbred, at breeding age, were used in this study. Initially, the females were submitted to ultrasound examination for negative diagnosis of pregnancy and, subsequently, hosted in stalls 
with the bucks for mating. Each male was marked daily with red paint on the chest. When red spots were observed in the lumbar region of the females, indicating possible mating, ultrasound examination was performed 25 days after the observation to confirm gestation by visualization of fetal heartbeat. After a positive diagnosis of gestation, pregnant goats were randomly assigned to three groups (Groups 1, 2, and 3).

Animals were fed with Amorimia septentrionalis collected weekly in the municipality of Teixeira (07²1 '24"S; $\left.37^{\circ} 15^{\prime} 11^{\prime \prime} \mathrm{W}\right)$, Paraíba state. One specimen of the plant was dried and deposited in the Herbarium of the Universidade Federal de Campina Grande, campus of Patos, Paraíba state, Brazil (checking copy no. 6702). Ten samples of leaves of A. septentrionalis were sent to the Poisonous Plant Laboratory, Agricultural Research Service, United States Department of Agriculture, Logan, USA, for detection and quantification of MF in its composition using the Gas Chromatograph-Mass Spectrometry (GC-MS) method described by Santos-Barbosa et al. (2017).

Group 1, composed of eight goats, received fresh leaves of A. septentrionalis in daily doses of $1 \mathrm{~g} / \mathrm{kg}$ body weight administered at three different periods during gestation: between days 91 to 100 , 116 to 125 , and from day 140 till delivery. The 15-day interval between each administration period was observed in order to detoxify MF, reducing the risk of death of females, and to induce their increased resistance to poisoning, as described by Duarte et al. (2014). The plant leaves were stored under refrigeration for up to one week, and supplied daily to the goats by placing small volumes directly in the animals' mouths.

In Group 2, composed of 10 goats, eight which also received $1 \mathrm{~g} / \mathrm{kg}$ body weight of $A$. septentrionalis, but the leaves had been previously left to dry in the shade for 10 days, and then milled. Dry matter percentage was $34.5 \%$. The dry plant was supplied to the goats from the 140th day of gestation till delivery. The other two female goats of this group did not ingest the plant during gestation and after delivery the colostrum supplied to their kids was replaced by that of goats of the same group that had ingested the dry plant in the end of gestation. The dried and milled plant leaves were stored in plastic buckets at room temperature and supplied to the animals mixed with the concentrated feed to facilitate ingestion.

Group 3, composed of eight goats, served as control, and animals in this group did not ingest $A$. septentrionalis.

During the experiment, each animal received daily food equivalent to $3 \%$ body weight, with $1 \%$ of concentrated feed and $2 \%$ of bulky feed (Tifton hay, Cynodon dactylon), and water ad libitum.

All pregnant females were monitored for viability of gestation through ultrasound examinations performed every 15 days. Prior to supply of $A$. septentrionalis, all animals were weighed and had their heart rate and respiratory and ruminal movements measured. Goats were monitored daily for observation of delivery or abortion. After delivery, all goats, except for the two goats in Group 2 that did not ingest the plant, had their colostrum collected and supplied to the respective kids, which were observed for a period of six hours after ingestion.

Colostrum that was not offered to the kids (in the case of abortion) or any surplus of it was frozen and subsequently administered to the kids from goats that did not ingest the plant during pregnancy. In the event of death or abortion, the animals were necropsied, samples of the organs were collected from the thoracic and abdominal cavities and the central nervous system, fixed in $10 \%$ formalin, embedded in paraffin, sectioned at 4-6 $\mu \mathrm{m}$, and stained with hematoxylin-eosin for histopathological examination.

\section{RESULTS}

All goats in Group 1 showed signs of poisoning, namely, depression, tachycardia, engorgement of the jugular veins, and reluctance to walk, remaining most of the time in sternal decubitus. These clinical signs began between the 2 nd and 8 th days of each of the three periods of plant administration. Recovery of the animals occurred within seven to 12 days after the end of the plant administration period, except in one of the goats that showed aggravated poisoning and, in addition to the clinical signs already described, showed peddling movements in lateral decubitus, nystagmus, and opisthotonus; euthanasia in extremis was performed on the 2 nd day of the third plant administration period. At necropsy, congestion of the encephalon vessels and distended bladder were observed. No significant histopathological lesion was found. Two goats had bloody vaginal discharge after eight and 28 days of plant ingestion respectively, and abortion of one fetus each. Four kids, from two goats, received colostrum and, after approximately 15 minutes, presented with depression, wheezing, lateral decubitus, and bleating, and evolved to death. Pulmonary edema and hydropericardium were found at necropsy. Two kids born during the night were found dead and, at necropsy, there were signs that they had been born alive: presence of colostrum in the abomasum and pulmonary aeration. No significant lesions were observed in the histopathological studies. One of the goats in Group 1 delivered two kids that, even after being fed with colostrum, showed no signs of poisoning (Table 1).

In Group 2, the eight goats that ingested dry plant leaves as of the 140th day of gestation presented with tachycardia and engorgement of the jugular veins, delivering 14 kids between two and five days after the beginning of plant consumption. Five deliveries were monitored, resulting in nine stillborn kids. Three goats delivered during the night, and the five resulting kids were found dead in the morning; necropsy showed that three of kids had air in the lungs, indicating that they were born alive. The other two animals had no pulmonary aeration. No colostrum was found in the abomasum of any of the five kids found dead in the morning, and no significant changes were observed during necropsy or histopathology. The three kids of the two goats that did not ingest the plant during gestation received colostrum, immediately after delivery, from the other three goats that had ingested the plant leaves in the end of gestation. The offspring were observed for six hours and showed no signs of poisoning (Table 1).

In Group 3 (control), all female goats kidded normal. The kids ingested colostrum and showed no sign of poisoning (Table 1).

The average amount of MF contained in the A. septentrionalis leaf samples was $0.00074 \% \pm 0.00018$.

\section{DISCUSSION}

Hyperacute death of kids, with clinical signs characteristic of sodium monofluoracetate (MF) poisoning, after consumption of colostrum from goats that ingested Amorimia septentrionalis confirm the hypothesis of elimination of MF in milk as a cause of poisoning. In contrast, in Group 2, administration of plant leaves in larger doses caused neonatal death, and it was not possible to demonstrate elimination of MF in milk. 
Table 1. Effect of ingestion of colostrum from goats that consumed Amorimia septentrionalis or not during gestation on their kids

\begin{tabular}{|c|c|c|c|c|c|c|c|}
\hline Group & Goat & $\begin{array}{l}\text { Plant ingestion } \\
\text { (days) }\end{array}$ & Abortion & Stillborn & $\begin{array}{l}\text { Death soon } \\
\text { after birth }\end{array}$ & $\begin{array}{l}\text { Death after feeding with } \\
\text { colostrum }\end{array}$ & $\begin{array}{c}\text { Alive even after feeding } \\
\text { with colostrum }\end{array}$ \\
\hline \multirow{8}{*}{$\begin{array}{c}\text { Group } 1 \\
\text { (1g/kg of fresh } \\
\text { leaves) }\end{array}$} & 1 & $22^{\mathrm{a}}$ & & & & & \\
\hline & 2 & 8 & 1 & & & & \\
\hline & 3 & 28 & 1 & & & & \\
\hline & 4 & 30 & & & & 2 & \\
\hline & 5 & 29 & & & & 2 & \\
\hline & 6 & 28 & & & & $1^{\mathrm{b}}$ & \\
\hline & 7 & 28 & & & & $1^{\mathrm{b}}$ & \\
\hline & 8 & 32 & & & & & 2 \\
\hline \multirow{10}{*}{$\begin{array}{c}\text { Group } 2 \\
\text { (1g/kg of dry } \\
\text { leaves })\end{array}$} & 1 & 4 & & 2 & & & \\
\hline & 2 & 2 & & 2 & & & \\
\hline & 3 & 5 & & 2 & & & \\
\hline & 4 & 4 & & 1 & & & \\
\hline & 5 & 5 & & 2 & & & \\
\hline & 6 & 4 & & 2 & & & \\
\hline & 7 & 5 & & & $2^{c}$ & & \\
\hline & 8 & 5 & & & $1^{\mathrm{c}}$ & & \\
\hline & 9 & 0 & & & & & 2 \\
\hline & 10 & 0 & & & & & 1 \\
\hline \multirow{8}{*}{$\begin{array}{l}\text { Group } 3 \\
\text { (control) }\end{array}$} & 1 & 0 & & & & & 2 \\
\hline & 2 & 0 & & & & & 1 \\
\hline & 3 & 0 & & & & & 2 \\
\hline & 4 & 0 & & & & & 2 \\
\hline & 5 & 0 & & & & & 2 \\
\hline & 6 & 0 & & & & & 2 \\
\hline & 7 & 0 & & & & & 1 \\
\hline & 8 & 0 & & & & & 1 \\
\hline
\end{tabular}

${ }^{\mathrm{a}}$ Kid showed clinical signs of poisoning and was submitted to euthanasia in extremis, ${ }^{\mathrm{b}}$ kids that were born during the night and were found dead the next morning (colostrum observed in the abomasum and airways during necropsy), ${ }^{\mathrm{c}}$ kids found dead and, at necropsy, air was observed in the lungs, indicating that they were born alive.

In a similar study, Vasconcelos et al. (2008), administered A. septentrionalis at a dose of $2 \mathrm{~g}$ of fresh plant leaves per $\mathrm{kg}$ of body weight to two goats and five sheep during the last 15 days of gestation. One kid from one of the goats died five minutes after being fed with colostrum and the other goat delivered a kid that died soon after birth without ingesting colostrum. As in the present study, the authors also observed abortion, which occurred with sheep that consumed the plant for 10 days. The clinical signs observed in the kids of Group 1 that died immediately after ingesting colostrum are similar to those described by Vasconcelos et al. (2008) in natural poisoning with $A$. septentrionalis in goats occurred in the municipality of Cabaceiras, Paraíba state, which included reluctance to walk, falls, lateral decubitus, peddling movements, tachypnea, bleating, and death. Absence of significant histopathological findings in intoxicated kids was also observed by Paraguassu (1983) in a series of experiments conducted with goats. The clinical signs and absence of histopathological findings observed in the kids that died immediately after ingesting colostrum are consistent with poisoning by $A$. septentrionalis, with milk from the goats as the only route of poisoning, considering that it was the only food source of the kids.

It has already been demonstrated that other plants in the semi-arid region also have phytotoxins eliminated in milk, causing poisoning of offspring that ingest it. Using mice as an experimental model, Lopes et al. (2014) demonstrated that the tremorgenic toxin present in Ipomoea asarifolia, or its metabolite, is eliminated in the milk of females that consume ration containing this plant, causing tremors and even the death of the offspring. Posteriorly, Carvalho de Lucena et al. (2014) also confirmed the occurrence of poisoning in lambs that ingested milk from ewes that fed exclusively on I. asarifolia.

Crotalaria spectabilis also affects the offspring in mice, either when the plant seeds are supplied together with the ration to lactating female mice or when monocrotaline (the plant toxic principle) is added to the feed, causing toxic effects such as weakness, ascites, and anasarca, both in the female mice and pups (Medeiros 1994).

Some active plant principles have also been found in dairy by-products. Alvarenga (2015) fed mice with ration containing cheese produced from the milk of cows that received Pteridium aquilinum, which contains ptaquiloside, a known carcinogen. At necropsy, the cows did not show any changes associated with poisoning, but the mice showed development of pre-neoplastic lesions in the stomach, intestines, and bladder.

Regarding the occurrence of abortion due to ingestion of $A$. septentrionalis, Silva et al. (2017) supplied $5 \mathrm{~g} / \mathrm{kg}$ body weight of fresh $A$. septentrionalis leaves, at the beginning of the fetal phase ( 36 days of gestation) and at the middle third (93 days of gestation) of the same phase, to four pregnant 
goats in each of these periods. Of the animals that ingested the plant at the beginning of the fetal phase, $75 \%$ aborted; whereas of the animals that received the plant in the middle third of the fetal phase, $50 \%$ aborted. The researchers suggested that the toxic effects on fetus decrease as gestation progresses. However, in the present experiment, the plant was ingested for a shorter time, in smaller amounts, and in the end of gestation, causing abortion in $75 \%$ of the goats in Group 2, which suggests that the effect of plant on reproduction is associated with the concentration of MF present in it, and not with gestational age. Sodium monofluoracetate was not quantified in plant samples used in the experiment conducted by Silva et al. (2017). In the present study, the amount of MF in the $A$. septentrionalis samples was $0.00074 \% \pm 0.00018$ and, although at a lower concentration than that observed by Lee et al. (2012) and Albuquerque et al. (2014), which was $0.002 \%$ of MF in the plant leaves, was able to cause poisoning, most likely by the repeated ingestion of small doses.

\section{CONCLUSION}

Amorimia septentrionalis causes abortion and its toxic active principle, sodium monofluoracetate (MF), is eliminated in milk and can result in neonatal deaths.

Ethics Committee.- This study was conducted in agreement with ethical principles on animal experimentation and was approved by the Ethics Committee on Animal Use of the UFCG under protocol no. 69-2013.

Conflict of interest statement.- The authors have no competing interests.

\section{REFERENCES}

Albuquerque S.S.C., Rocha B.P., Almeida V.M., Oliveira J.S., Riet-Correa F., Lee S.T., Evêncio Neto J. \& Mendonça F.S. 2014. Fibrose cardíaca associada à intoxicação por Amorimia septentrionalis em bovinos. Pesq. Vet. Bras. 34(5):433-437. <http://dx.doi.org/10.1590/S0100-736X2014000500008>

Alvarenga T.M.P. 2015. Avaliação clinicopatológica de ratos alimentados com queijo de leite de vacas que consumiam Pteridium aquilinum. Masters Thesis, Universidade Federal de Lavras, Lavras, MG. 88p.

Carvalho G.D., Nunes L.C., Bragança H.B.N. \& Porfírio L.C. 2009. Principais plantas tóxicas causadoras de morte súbitas em bovinos no estado do Espírito Santo, Brasil. Arch. Zootec. 58:87-98.

Carvalho de Lucena K.F., Rodrigues J.M., Campos É.M., Dantas A.F., Pfister J.A., Cook D., Medeiros R.M. \& Riet-Correa F. 2014. Poisoning by Ipomoea asarifilia in lambs by the ingestion of milk from ewes that ingest the plant.
Toxicon 92:129-132.<http://dx.doi.org/10.1016/j.toxicon.2014.10.019> <PMid:25448387>

Duarte A.L., Medeiros R.M.T. \& Riet-Correa F. 2013. Intoxicação por Amorimia spp. em ruminantes. Ciência Rural 43(7):1294-1301. <http://dx.doi. org/10.1590/S0103-84782013005000081>

Duarte A.L., Medeiros R.M., Carvalho F.K., Lee S.T., Cook D., Pfister J.A., Costa V.M. \& Riet-Correa F. 2014. Induction and transfer of resistance to poisoning by Amorimia (Mascagnia) septentrionalis in goats. J. Appl. Toxicol 34(2):220-223. <http://dx.doi.org/10.1002/jat.2860><PMid:23400835>

Lee S.T., Cook D., Riet-Correa F., Pfister J.A., Anderson W.R., Lima F.G. \& Gardner D.R. 2012. Detection of monofluoroacetate in Palicourea and Amorimia species. Toxicon 60(5):791-796. <http://dx.doi.org/10.1016/j. toxicon.2012.05.029><PMid:22699106>

Lopes J.R.G., Riet-Correa F., Cook D., Pfister J.A. \& Medeiros R.M.T. 2014 Elimination of the tremorgenic toxin of Ipomoea asarifolia by milk. Pesq. Vet. Bras. 345(11):1085-1088. <http://dx.doi.org/10.1590/S0100736X2014001100009>

Medeiros R.M.T.M. 1994. Veiculação do princípio tóxico de Crotalaria spectabilis (Roth) em leite de cabra e rata: uma avaliação toxicológica. Masters Thesis, Faculdade de Medicina Veterinária e Zootecnia da Universidade de São Paulo, São Paulo. 143p.

Paraguassu A.A. 1983. Intoxicação experimental por Mascagnia rigida Grisebach (Malpighiaceae) em caprinos no Nordeste do Brasil. Masters Thesis, Universidade Federal Rural do Rio de Janeiro, Itaguaí. 65p.

Santos-Barbosa J.M., Lee S.T., Cook D., Gardner D.R., Viana L.H. \& Ré N. 2017 A gas chromatography-mass spectrometry method for the detection and quantitation of monofluoroacetate in plants toxic to livestock. J. Agricult. Food Chem. 65(7):1428-1433. <http://dx.doi.org/10.1021/acs.jafc.7b00294> <PMid:28132508>

Silva L.C.A., Pessoa D.A.N., Lopes R.G., Santos J.R.S., Olinda R.G. \& Riet-Correa F. 2017. Embryonic death and abortions in goats caused by the ingestion of Amorimia septentrionalis. Pesq. Vet. Bras. 37(12):1401-1404. <http:// dx.doi.org/10.1590/s0100-736x2017001200007>

Soares M.P., Pavarini S.P., Adrien Mde.L., Quevedo Pde.S., Schild A.L., Peixoto P.V., da Cruz C.E. \& Driemeier D. 2011. Amorimia exotropica poisoning as a presumptive cause of myocardial fibrosis in cattle. J. Vet. Diagn. Invest. 23(6):1226-1229. <http://dx.doi.org/10.1177/1040638711425586> <PMid:22362807>

Tokarnia C.H., Brito M.F., Barbosa J.D., Peixoto P.V. \& Döbereiner J. 2012. Plantas Tóxicas do Brasil para Animais de Produção. 2a ed. Helianthus, Rio de Janeiro, p.27-71.

Vasconcelos J.S., Riet-Correa F., Dantas A.F.M., Medeiros R.M.T., Galiza G.J.N., Oliveira D.M. \& Pessoa A.F.A. 2008. Intoxicação por Mascagnia rigida (Malpighiaceae) em ovinos e caprinos. Pesq. Vet. Bras. 28(10):521-526. <http://dx.doi.org/10.1590/S0100-736X2008001000013> 